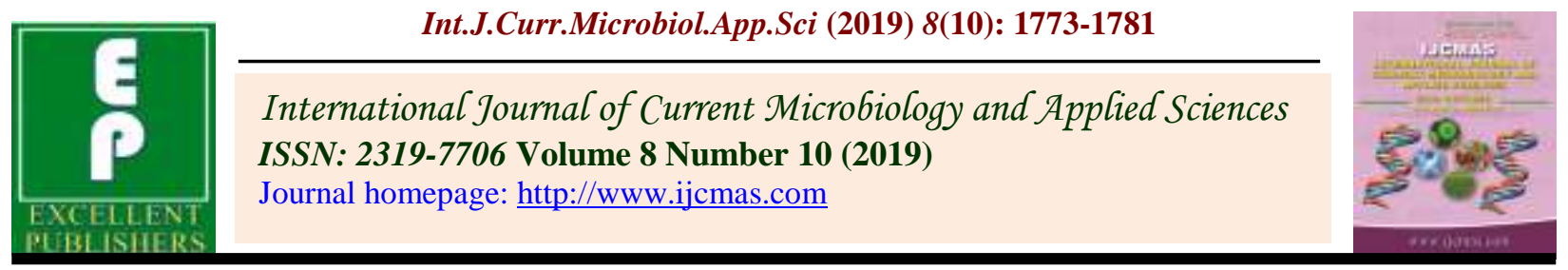

Original Research Article

https://doi.org/10.20546/ijcmas.2019.810.206

\title{
In vitro Evaluation of Bioagents against Fusarium Wilt of China Aster caused by Fusarium oxysporum f. sp. Callistephi and its effect on Growth Parameters under Pot Condition
}

\author{
G. Krishna ${ }^{1}$, S. K. Nataraj ${ }^{1}$, R. Rajeshwari ${ }^{2}$, B. N. Kirtimala ${ }^{3}$ and H. Nagaraj ${ }^{4}$ \\ ${ }^{1}$ Department of Floriculture and Landscape Architecture, ${ }^{4}$ Department of Plant Pathology, \\ College of Horticulture, Mudigere, India \\ ${ }^{2}$ Department of Plant Pathology, College of Horticulture, Mysuru, India \\ ${ }^{3}$ Department of Floriculture and Landscape Architecture, College of Horticulture, \\ Mysuru, India \\ *Corresponding author
}

\section{A B S T R A C T}

Keywords

China aster,

Bioagents,

Trichoderma

harzianum,

Fusarium

oxysporum f. sp.

Callistephi

Article Info

Accepted:

12 September 2019

Available Online:

10 October 2019
The present study was conducted by using six bioagents against fusarium wilt of China aster caused by Fusarium oxysporum f. sp. callistephi under in vitro condition during the year 2018-19. Among the bioagents Trichoderma harzianum was found significantly superior over other bioagents in arresting the growth of pathogen and exhibited 90.06 per cent inhibition with respect to effect of bioagents alone and with fusarium inoculated treatments on growth parameters under pot culture. It was revealed that the treatment Trichoderma harzianum alone recorded significantly higher growth parameters like maximum plant height (57.67 $\mathrm{cm}$ ), number of branches per plant (3.78), plant spread $\left(463.42 \mathrm{~cm}^{2}\right.$ ), maximum days to first flowering (64.33) was taken and maximum number of flowers per plant (22.50) respectively compare to control.

\section{Introduction}

China aster [Callistephus chinensis (L.) Nees.] is an important winter annual flower and ornamental plant, belonging to the family Asteraceae, with the diploid chromosome number of $2 n=18$. The crop is native to China, spread to Europe and other tropical countries in 1731 A.D (Desai, 1967). The genus Callistephus is derived from two Greek words Kalistos meaning 'most beautiful' and Stephos 'a crown' referring to the flower head. It was first named by Linnaeus as Aster chinensis and Nees changed to Callistephus chinensis (Janakiram, 2006). The crop is cultivated throughout the world for cut flower, loose flower, in garden as flower beds and borders. In India, China aster is commercially 
grown in the states of Karnataka, Tamilnadu, Maharashtra, Telangana, Andhra Pradesh, and West Bengal (Ramya et al., 2019). In Karnataka, it is widely cultivated in Bengaluru, Chitradurga, Tumkur, Belagavi, Gadag, Bagalkot and Kolar districts in an area of 2,194 hectares with total production of 20,646 MT and the productivity of $9.41 \mathrm{t} / \mathrm{ha}$ (Anon, 2015). It is grown successfully in an open condition during kharif, rabi and summer seasons for year around supply of flowers.

The major production constraints of China aster are the incidence of fungal diseases such as fusarium wilt and botrytis. Among these fusarium wilt is the most destructive one and causes substantial crop yield loss (Horita et al., 2016). Fusarium oxysporum is a welldescribed soil-borne fungus (Gordon and Martyn, 1997) includes wide diversity of strains responsible for wilts or rots on many plant species (Dean et al., 2012). F. oxysporum-induced diseases cause serious damage during production and storage (Gullino et al., 2015). Though the chemical control is a regular practice in managing the disease, continuous use of fungicides leads to a pollution problems, residual effects, toxicity resistance in pathogen, and imbalance in soil microbial association. Therefore, alternative means of disease control are advisable. The use of biocontrol agents offers good control of many soil pathogens like Fusarium sp. (Negi and Raj, 2016). The present investigation was undertaken with a view to study the effect of different bioagents alone under in vitro with combination of fusarium inoculation in pot culture for the control of fusarium wilt.

\section{Materials and Methods}

The in vitro and pot culture experiment was carried out in the Department of Floriculture and landscape architecture, College of Horticulture, Mudigere, during 2018-19.

\section{Isolation and maintenance of culture}

The China aster plants showing typical symptoms of fusarium wilt were collected from field and the causal fungus was isolated by adopting the standard tissue isolation technique. Later, the bit of fungal growth was transferred to PDA slants for purification and maintenance of the culture.

\section{Evaluation of bioagents}

Totally six bioagents were used for study viz., $\mathrm{T}_{1}$-Trichoderma asperellum, $\quad \mathrm{T}_{2}$ Pseudomonas fluorescens, T3-Arka Microbial Consortium (AMC), $\mathrm{T}_{4^{-}}$Azorhizophilus spp. (K solubilising bacteria), T5-Bacillus subtilis, T6-Trichoderma harzianum were tested in vitro against Fusarium oxysporum f. sp. callistephi by using dual culture technique (Dennis and Webster, 1971). These bioagents were obtained from College of Horticulture, Mysuru.

\section{Dual culture technique}

Twenty $\mathrm{ml}$ of sterilized and cooled potato dextrose agar was poured into sterile Petri plates and allowed to solidify. For evaluation of fungal biocontrol agents, mycelial discs of Fusarium oxysporum f.sp. callistephi were inoculated at one end of the Petri plate and antagonistic fungus was placed opposite to it on the other end. In case of evaluation of bacterial antagonist, the bacterium was streaked one day earlier at one end of the Petri plate to the middle of the Petri plate and the test fungus placed at the other end. The plates were incubated at $27 \pm 1^{\circ} \mathrm{C}$ and zone of inhibition was recorded by measuring the clear distance between the margin of the Fusarium oxysporum f.sp. callistephi and antagonistic organism. The colony diameter of pathogen in control plate was also recorded. The per cent inhibition of growth of the pathogen was calculated by using the formula suggested by 
Vincent (1947).

$$
\mathrm{PI}=\frac{\mathrm{C}-\mathrm{T}}{\mathrm{T}} \times 100
$$

Where,

PI - Per cent inhibition

C - The growth of test pathogen $(\mathrm{mm})$ in the absence of the antagonist.

$\mathrm{T}$ - The growth of test pathogen $(\mathrm{mm})$ in the presence of the antagonist.

\section{Pot experiment}

The experimental design was Completely Randomized Design (CRD) with fourteen treatments and three replications for the statistical analysis. Eighty four pots were collected and the sterilized soil mixture (i.e. soil mixed with FYM was treated with hydrogen peroxide @ $30 \mathrm{ml}$ per litre of water/ $\mathrm{m}^{2}$ for soil sterilization and left it for sun drying) was filled in pot and kept in shade house. Next day, one month old rooted China aster seedlings ( 3 seedling/ pot) were planted.

The plants were treated with bioagents alone and fusarium inoculated culture prepared in laboratory. The treatments were given by drenching different bioagents and fusarium culture of about $50 \mathrm{ml}$ suspended pure culture around the root zone of plants within 10 days after transplanting of seedlings. Treatment details were $\mathrm{T}_{1}$ - Trichoderma asperellum + Fusarium oxysporum f. sp. callistephi, $\mathrm{T}_{2^{-}}$ Pseudomonas fluorescens + Fusarium oxysporum f. sp. callistephi, $\mathrm{T}_{3^{-}}$Arka Microbial Consortium (AMC) + Fusarium oxysporum f. $\mathrm{sp}$. callistephi, $\mathrm{T}_{4^{-}}$ Azorhizophilus spp. + Fusarium oxysporum f. sp. callistephi, $\mathrm{T}_{5^{-}}$Bacillus subtilis + Fusarium oxysporum f. sp. callistephi, $\mathrm{T}_{6^{-}}$ Trichoderma harzianum + Fusarium oxysporum f. sp. callistephi, $\mathrm{T}_{7}$ Fusarium oxysporum f. sp. Callistephi, $\mathrm{T}_{8^{-}}$Trichoderma asperellum, $\mathrm{T}_{9^{-}}$Pseudomonas fluorescens, $\mathrm{T}_{10^{-}}$Arka Microbial Consortium (AMC), $\mathrm{T}_{11^{-}}$ Azorhizophilus spp., $\mathrm{T}_{12-}$ Bacillus subtilis, $\mathrm{T}_{13^{-}}$ Trichoderma harzianum, $\mathrm{T}_{14^{-}}$Control (Untreated).

The effect of different bioagents on growth of China aster was determined by taking observations of plant height $(\mathrm{cm})$, number of branches per plant, plant spread $\left(\mathrm{cm}^{2}\right)$, days to first flowering and number of flowers per plant.

\section{Results and Discussion}

In vitro evaluation of bioagents against Fusarium oxysporum f. sp. callistephi

The antagonistic effect of six biocontrol agents were evaluated against Fusarium oxysporum f. sp. callistephi and the results are presented in Table 1 and Plate 1 . The highest per cent inhibition was noticed in $\mathrm{T}_{6^{-}}$ Trichoderma harzianum (90.06\%). The next best treatment was observed in $T$. asperellum (86.28\%), Arka Microbial Consortium (77.78 $\%)$, P. fluorescens (67.28 \%), B. subtilis $(61.11 \%)$. Whereas, least per cent inhibition was recorded in the treatment Azorhizophilus spp. (37.56\%) compare to other treatments. This inhibition may be due to volatile and non-volatile metabolites and cell wall degrading enzymes produced by Trichoderma sp.

This may be also due to undeniably its mode of action like competition, antibiosis and mycoparasitim and it possess some important secondary metabolites and antibiotics like viridin, harzianiol and so many. These findings are also in conformity with Pawan and Vijay (2011) in chrysanthemum, Kishore et al., (2007) in gerbera, Rajput et al., (2013) in marigold, Kavita et al., (2017) in carnation. 
Effect of bioagents and Fusarium oxysporum f. sp. callistephi inoculation on growth and flowering of China aster under pot condition

The differences in the plant height as influenced by different bioagents and fusarium inoculated treatments were found significant and it ranged from $30.78 \mathrm{~cm}$ to $57.67 \mathrm{~cm}$ (Table 2). Among the bioagents and fusarium inoculated treatments, the higher plant height $(57.67 \mathrm{~cm})$ was observed in the bioagent Trichoderma harzianum $\left(\mathrm{T}_{13}\right)$ alone, it is on par with T. asperellum $(56.46 \mathrm{~cm})$ and Arka Microbial Consortium $(55.67 \mathrm{~cm})$. The next best combined treatment were T. harzianum + F. oxysporum f. sp. callistephi $(54.33 \mathrm{~cm}), T$. asperellum $+F$. oxysporum f. sp. callistephi $(54.00 \mathrm{~cm})$ were recorded higher plant height. Significantly, minimum plant height was recorded in $F$. oxysporum f. sp. callistephi $(30.78 \mathrm{~cm})$ compare to other treatments. Bioagents produce several growth promoting hormones (auxins, cytokinins and gibberellins etc.) in addition to increasing the availability of nitrogen and phosphorus to the plants resulting in better plant growth. These results are in conformity with the findings of Brandler et al., (2017) in gerbera, Ramakrishna et al., (2013) in gladiolus, Nosir
(2016) in tuberose, Manooanjitham et al., (2000) in chilli.

The differences in the number of branches per plant as influenced by different bioagents and fusarium inoculated treatments were found significant and it ranged from 2.78 to 3.78 (Table 2). Among the bioagents and fusarium inoculated treatments, the maximum number of branches per plant (3.78) was observed in the bioagent Trichoderma harzianum $\left(\mathrm{T}_{13}\right)$ alone, it is on par with T. asperellum (3.67), Arka Microbial Consortium (3.67) and Azorhizophilus spp. (3.58). The combined treatment $T$. harzianum + Fusarium oxysporum f. sp. callistephi (3.42), $T$. asperellum $+F$. oxysporum f. sp. callistephi (3.42) were next best treatments recorded maximum number of branches per plant. Significantly, minimum numbers of branches per plant were recorded in the $F$. oxysporum $\mathrm{f}$. sp. callistephi (2.78) compare to other treatments. These results may be due to the role of bioagents in nutrient uptake and production of growth promoting substances such as indole acetic acid and gibberellins which led to more number of flowering branches per plant. These results are in agreement with the reports of Brandler et al., (2017) in gerbera.

Table.1 In vitro evaluation of bioagents against Fusarium oxysporum f. sp. callistephi

\begin{tabular}{|c|c|}
\hline Treatments & Per cent inhibition (\%) \\
\hline T1- Trichoderma asperellum & 86.28 \\
\hline T2- Pseudomonas fluorescens & 67.28 \\
\hline T3- Arka Microbial Consortium & 77.78 \\
\hline T4- Azorhizophilus spp. & 37.56 \\
\hline T5- Bacillus subtilis & 61.11 \\
\hline T6- Trichoderma harzianum & 90.06 \\
\hline S. Em. \pm & 0.72 \\
\hline CD @ 1\% & 2.82 \\
\hline
\end{tabular}


Table.2 Effect of bioagents and Fusarium oxysporum f. sp. callistephi inoculation on growth parameters of China aster under pot condition

\begin{tabular}{|c|c|c|c|c|c|}
\hline Treatments & $\begin{array}{l}\text { Plant } \\
\text { height } \\
(\mathbf{c m})\end{array}$ & $\begin{array}{l}\text { Number } \\
\quad \text { of } \\
\text { branches } \\
\text { per plant }\end{array}$ & $\begin{array}{l}\text { Plant } \\
\text { spread } \\
\left(\mathrm{cm}^{2}\right)\end{array}$ & $\begin{array}{l}\text { Days to } \\
\text { first } \\
\text { flowering }\end{array}$ & $\begin{array}{l}\text { Number } \\
\text { of flowers } \\
\text { per plant }\end{array}$ \\
\hline $\begin{array}{l}\text { T1- Trichoderma asperellum } \\
+ \text { Fusarium oxysporum f. sp. } \\
\text { callistephi }\end{array}$ & 54.00 & 3.42 & 394.21 & 68.25 & 14.10 \\
\hline $\begin{array}{c}\mathrm{T}_{2}-\text { Pseudomonas } \\
\text { fluorescens + Fusarium } \\
\text { oxysporum f. sp. callistephi }\end{array}$ & 49.40 & 3.22 & 364.73 & 68.33 & 12.00 \\
\hline $\begin{array}{c}\text { T3-Arka Microbial } \\
\text { Consortium + Fusarium } \\
\text { oxysporum f. sp. callistephi }\end{array}$ & 53.89 & 3.35 & 381.36 & 68.40 & 14.00 \\
\hline $\begin{array}{l}\text { T4-Azorhizophilus spp. + } \\
\text { Fusarium oxysporum f. sp. } \\
\text { callistephi }\end{array}$ & 53.67 & 3.33 & 356.76 & 68.50 & 10.33 \\
\hline $\begin{array}{c}\text { T5- Bacillus subtilis + } \\
\text { Fusarium oxysporum f. sp. } \\
\text { callistephi }\end{array}$ & 45.42 & 3.22 & 338.80 & 68.78 & 8.67 \\
\hline $\begin{array}{l}\text { T6- Trichoderma harzianum } \\
+ \text { Fusarium oxysporum f. sp. } \\
\text { callistephi }\end{array}$ & 54.33 & 3.42 & 406.89 & 68.18 & 16.00 \\
\hline 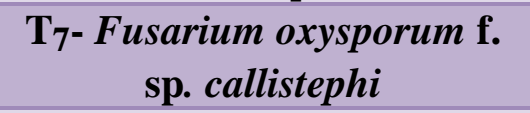 & 30.78 & 2.78 & 323.16 & 70.33 & 6.12 \\
\hline T8- Trichoderma asperellum & 56.46 & 3.67 & 450.40 & 64.78 & 22.22 \\
\hline $\begin{array}{c}\text { T9- Pseudomonas } \\
\text { fluorescens }\end{array}$ & 54.89 & 3.50 & 425.21 & 65.78 & 20.89 \\
\hline $\begin{array}{c}\text { T10- Arka Microbial }_{10} \\
\text { Consortium }\end{array}$ & 55.67 & 3.67 & 438.81 & 66.33 & 21.34 \\
\hline T11-Azorhizophilus spp. & 55.27 & 3.58 & 434.81 & 67.22 & 21.22 \\
\hline $\mathbf{T}_{12-}$ Bacillus subtilis & 54.78 & 3.44 & 416.09 & 67.44 & 20.67 \\
\hline $\mathbf{T}_{13-}$ Trichoderma harzianum & 57.67 & 3.78 & 463.42 & 64.33 & 22.50 \\
\hline T14- Control (Untreated) & 54.50 & 3.42 & 412.89 & 68.11 & 19.00 \\
\hline S. Em. \pm & 0.50 & 0.05 & 6.15 & 0.60 & 0.26 \\
\hline CD@1\% & 2.14 & 0.20 & 24.03 & 2.44 & 1.03 \\
\hline
\end{tabular}


Plate.1 In vitro dual culture technique

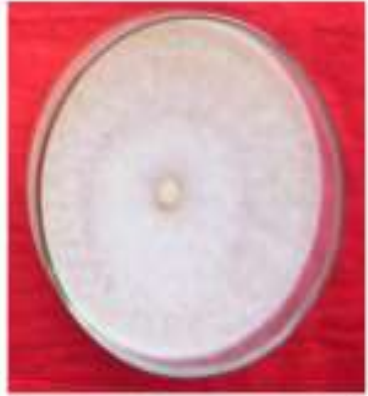

Fusarium oxysportum f. sp. callistephi

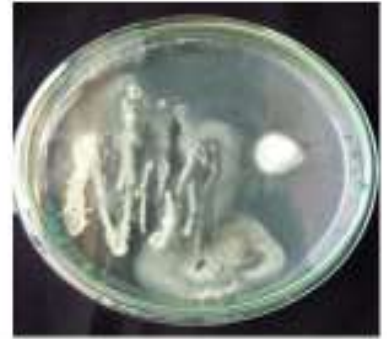

Pseudomonas fluorescens +

Fusarium oxysporum $\mathrm{f}$, sp. callistephi

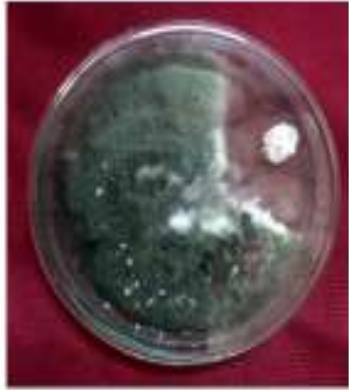

Trichoderma harstamim

+ Fusarium oxysporym $\mathrm{f}$. sp. callistephi

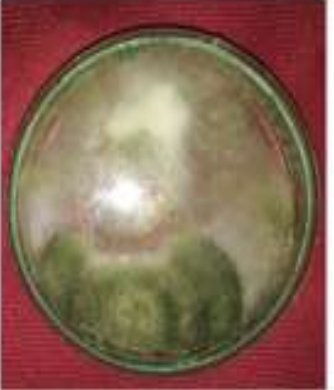

Trichoderma asperellum

+ Fusarium orysporum f. sp. callistephit

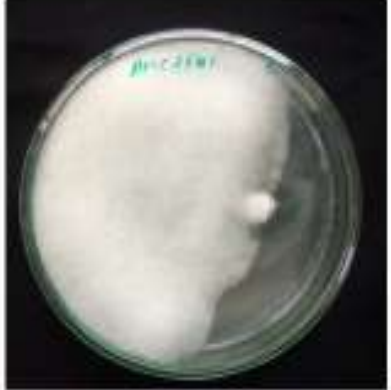

Arka Microbial Consortium + Fusarium oxysportum $\mathrm{f}$. sp. callistephi

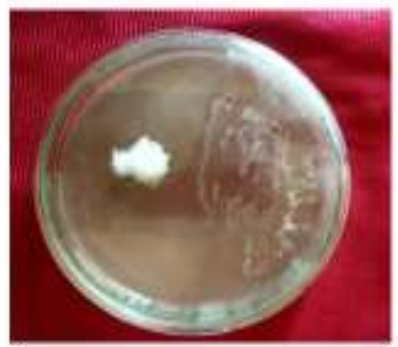

Bacillus subtilis + Fusarium oxysporum $\mathrm{f}$. sp. callistepht

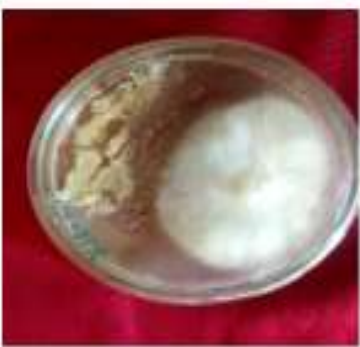

Azorhizophiths spp. + Fusarium oxysporum $\mathrm{f}, \mathrm{sp}$, callistephi

Plate.2 Comparison of Trichoderma harzianum and Fusarium inoculated treatment under pot condition

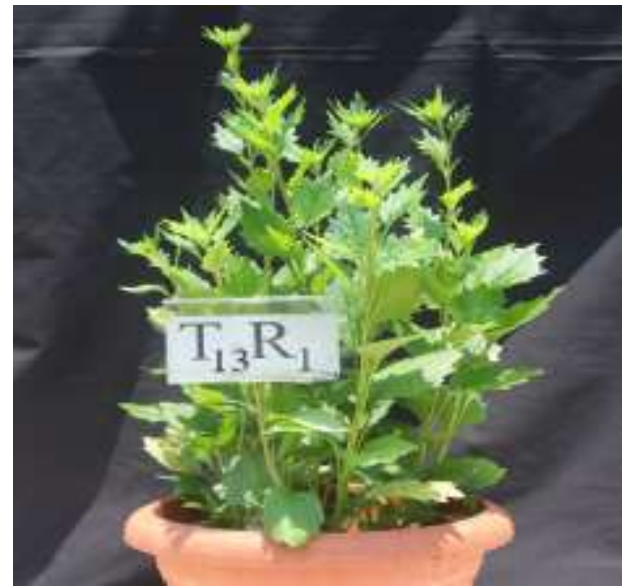

Trichoderma harzianum

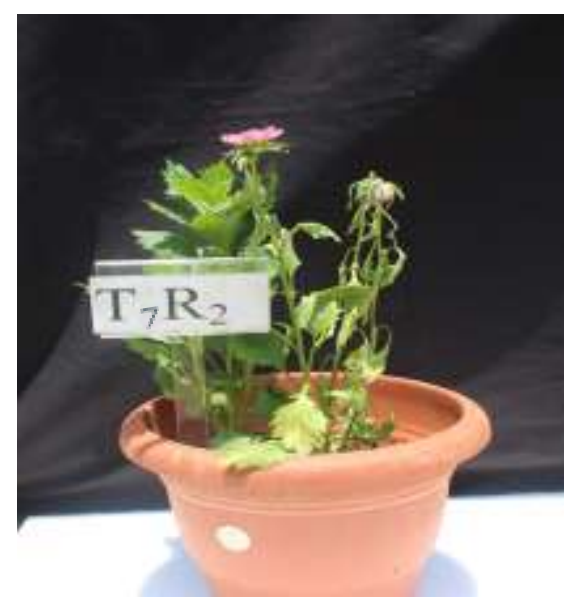

Fusarium inoculated 
The differences in the plant spread as influenced by different bioagents and Fusarium inoculated treatments were found significant and it ranged from $323.16 \mathrm{~cm}^{2}$ to $463.42 \mathrm{~cm}^{2}$ (Table 2). Among the bioagents and fusarium inoculated treatments, the maximum plant spread $\left(463.42 \mathrm{~cm}^{2}\right)$ was observed in the bioagent Trichoderma harzianum $\left(\mathrm{T}_{13}\right)$ alone, it is on par with $T$. asperellum $\left(450.40 \quad \mathrm{~cm}^{2}\right)$. The combined treatments T. harzianum + Fusarium oxysporum f. sp. callistephi $\left(406.89 \mathrm{~cm}^{2}\right), T$. asperellum $+F$. oxysporum f. sp. callistephi $\left(394.21 \mathrm{~cm}^{2}\right)$ were recorded maximum plant spread. Significantly, minimum plant spread was recorded in the $F$. oxysporum f. sp. callistephi $\left(323.16 \mathrm{~cm}^{2}\right)$ compare to other treatments. Maximum plant spread could be due to the increase in stem girth and number of branches per plant. These results are similar to Brandler et al., (2017) in gerbera, Ramakrishna et al., (2013) in gladiolus, Manooanjitham et al., (2000) in chilli.

The differences in the days for first flowering as influenced by different bioagents and fusarium inoculated treatments were found significant and it ranged from 64.33 days to 70.33 days (Table 2). Among the bioagents and fusarium inoculated treatments, the minimum days for first flowering 64.33 days was observed in the bioagent Trichoderma harzianum $\left(\mathrm{T}_{13}\right)$ alone, it is on par with $T$. asperellum (64.78 days), Pseudomonas fluorescens (65.78 days) and Arka Microbial Consortium (66.33 days). The combined treatments $T$. harzianum + Fusarium oxysporum f. sp. callistephi (68.18 days), $T$. asperellum $+F$. oxysporum f. sp. callistephi (68.25 days) were recorded minimum days for first flowering. Significantly, maximum days for first flowering was observed in the $F$. oxysporum f. sp. callistephi (70.33 days) compare to other treatments. The reason for earliness in flowering can be proper uptake of nutrients and production of growth promoting substances like auxins, gibberellins, vitamins and organic acids by the T. harzianum. Thereby, plant completed its vegetative growth soon, resulting in early flowering. These finding are in conformity with the findings of Brandler et al., (2017) in gerbera, Ramakrishna et al., (2013) in gladiolus, Nosir (2016) in tuberose.

The differences in the number of flowers per plant as influenced by different bioagents and fusarium inoculated treatments were found significant and it ranged from 6.12 to 22.50 across different treatment (Table 2). Among the bioagents and fusarium inoculated treatments, the maximum number of flowers per plant 22.50 were observed in the bioagent Trichoderma harzianum $\left(\mathrm{T}_{13}\right)$ and it is on par with T. asperellum (22.22) and Arka Microbial Consortium (21.34). The combined treatments $T$. harzianum $+F$. oxysporum $\mathrm{f}$. sp. callistephi (16.00), $T$. asperellum $+F$. oxysporum f. sp. callistephi (14.10) were recorded maximum number of flowers per plant. Significantly, minimum number of flowers per plant were recorded in the $F$. oxysporum f. sp. callistephi (6.12) compared to other treatments. The T. harzianum had recorded maximum plant height, more number of branches, plant spread and it was early flowering and resulted in more number of flowers per plant. The increase in number of flowers may be due to possible role of bioagents through better root proliferation, uptake of nutrients and water. Besides this, increase in flower yield may be attributed to increased availability of phosphorous and its greater uptake due to application of Trichoderma. Similar results were obtained by Brandler et al., (2017) in gerbera, Ramakrishna et al., (2013) in gladiolus, Nosir (2016) in tuberose.

The present study conclude that Trichoderma harzianum inhibited the mycelial growth of Fusarium oxysporum f. sp. callistephi 
effectively under in vitro and among different bioagents and fusarium inoculated treatments maximum vegetative growth and flowering was reported with Trichoderma harzianum under pot condition.

\section{References}

Anonymous. 2015. Horticultural Crops Statistics of Karnataka State at a Glance, Government of Karnataka, Department of Horticulture, Lalbagh, Bangalore.

Brandler, D., Divensi, L.J., Tonin, R.J., Pilla, T.P., Rezendes, I. and Milanesi, P.M. 2017. Evaluation of biological control of fusarium wilt in gerbera with Trichoderma asperellum. Ornamental Horticulture. 23(3): 234-239.

Dean, R., Van kan, J.A.L., Pretorius, Z.A., Hammond-kosack, K.E., Di pietro, A., Spanu, P.D., Rudd, J.J., Dickman, M., Kahmann, R., Ellis, J. and Foster, G.D. 2012. The Top 10 fungal pathogens in molecular plant pathology. Molecular Plant Pathology. 13: 414-430.

Dennis, C. and Webster, J. 1971. Antagonistic properties of species groups of Trichoderma II. Production of volatile antibiotics. Trans. British Mycological Society. 57: 41-48.

Desai, B.L. 1967. Flower description in China aster (Callistephus chinensis) in seasonal flowers. ICAR Publication, New Delhi. Pp. 53-56.

Gordon, T.R. and Martyn, R.D. 1997. The evolutionary biology of Fusarium oxysporum. Annual Revision of Phytopathology. 35: 111-128.

Gullino, M.L., Daughtrey, M.L., Garibaldi, A. and Elmer, W.H. 2015. Fusarium wilts of ornamental crops and their management. Crop Protection. 73: 5059.

Horita, H. and Mcgover, R.J. 2016. Diseases of China aster. Handbook of florists crops diseases. Pp. 1-20.

Kavita, T.H., Narayanaswamy, H., Kavitha, S.V. and Manu, T.G. 2017. Efficacy of bio-agents, botanicals and fungicides against Fusarium oxysporum f. sp. dianthi causing wilt of carnation. International Journal of Chemical Studies. 5(6): 139-142.

Kishore, C., Kulkarni, S., Hegde, Y.R., Jahagirdar, S. and Patil, A.A. 2007. Studies on diagnosis and management of fungal wilt diseases of carnation and gerbera under protected cultivation. M.Sc. (Agri.) Thesis, University of Agricultural Sciences Dharwad, Karnataka, India.

Manooanjitham, S.K., Prakasam, V., Rajappan, K. and Amutha, G. 2000. Control of chilli damping off using bioagents. Journal of Mycology and Plant Pathology. 30(2): 225-228.

Negi, H.S. and Raj, H. 2016. Integration of biocontrol agents and soil amendments for the management of fusarium wilt in carnation. Journal of Mycology and Plant Pathology. 43(3): 367-387.

Nosir, W.S. 2016. Trichoderma harzianum as a growth promoter and bio-control agent against Fusarium oxysporum f. sp. tuberosi. Advances in Crop Science Technology. 4: 217.

Pawan, K.S. and Vijay, K. 2011. Biological control of fusarium wilt of chrysanthemum with Trichoderma and botanicals. Journal of Agricultural Technology. 7(6): 1603-1613.

Rajput, R.B., Solanky, K.U., Prajapati, V.P., Pawar, D.M. and Suradkar, S.R. 2013. Effect of fungal and bacterial bioagents against Alternaria alternata in marigold under in vitro condition. The Bioscan. 8(2): 627-629.

Ramakrishna, K.R., Potdukhe, S.R., Guldekar, D.D., Chopde, N.K. and Dangore, U.T. 2013. Integrated disease management of (Fusarium oxysporum f. sp. 
gladioli) wilt of gladiolus. M.Sc. (Agri.) Thesis, University of Agricultural Science, PDKV, Akola.

Ramya, H.M., Nataraj, S.K. and Rajiv, K. 2019. Character Association and Path Coefficient Analysis in $\mathrm{F}_{2}$ Segregating Population of Cross "Arka Kamini x PG Violet" in China aster
(Callistephus chinensis [L.] Nees). International Journal of Currurent Microbiology and Applied Sciences. 8(4): 1314-1318.

Vincent, J.M. 1947. Distortion of fungal hyphae in the presence of certain inhibitors. Nature. 150: 850.

\section{How to cite this article:}

Krishna, G., S. K. Nataraj, R. Rajeshwari, B. N. Kirtimala and Nagaraj, H. 2019. In vitro Evaluation of Bioagents against Fusarium Wilt of China Aster caused by Fusarium oxysporum f. sp. Callistephi and its effect on Growth Parameters under Pot Condition. Int.J.Curr.Microbiol.App.Sci. 8(10): 1773-1781. doi: https://doi.org/10.20546/ijcmas.2019.810.206 